\title{
Use of Customer Relationship Management Application for Credit Union
}

\author{
Samuel Manurung ${ }^{1}$, Mufria.J.Purba ${ }^{2}$ \\ ${ }^{1}$ Universitas Methodist Indonesia, Faculty Of Computer Science, Medan, Indonesia \\ ${ }^{2}$ Universitas Methodist Indonesia, Faculty Of Economy,Medan, Indonesia \\ Samuelvanbastenmanurung070189@gmail.com
}

\begin{abstract}
Purpose: This research can help cooperatives and cooperative members to conduct transactions and help members with notification of the funds spent and the date of the last payment of the paper.

Design/methodology/approach: by using a RAD method can fulfill what the customer wants with a method that is done more quickly and makes it easier for business people in running their business

Findings: The Customer Relationship Management (CRM) application can support the notification process and simplify the cooperative payment process.

Research limitations/implications: Kabanjahe The majority

Practical implications: The existence of a savings and loan unit can help people in the Kabanjahe region to open a business to improve the economy of people in Kabanjahe. Therefore, we need a system that is very helpful in the cooperative's transaction process.

Originality/value:

Paper type: This paper can be categorized as case study paper.

Keyword: Index - Aplication, Cooperative, CRM, Notifications, transactions

Received : July $10^{\text {th }} 2019$

Revised : August $17^{\text {th }} 2019$

Published : September $30^{\text {th }} 2019$
\end{abstract}

\section{INTRODUCTION}

In daily life, cooperative is very much needed as a unit to assist in meeting the needs of the general public and especially small and simple communities. When people need funds in daily life, cooperatives are very suitable if in something we want, we must be paid in cash, especially in opening a business in the Kabanjahe area.

In order to ease the burden on the community in the Kabanjahe area, cooperatives are needed to overcome difficulties in using cooperatives and supporting information in cooperatives. In the process of lending, there is often a delay in the payment of cooperatives, making the value of arrears even greater because the people in the area have a busy life in the business and forget to make payments. Therefore we need a system that can help people in the Kabanjahe area.

As technology has increasingly advanced until now, at least all existing fields have used the techniques of renewal from IT (Science Technology). That is because the development of IT is now widely used to help the activities of the community. How can making a job more cheap, right on target, and get a satisfying result for the community. In this system, it will build the community in making it easier for the people in Kaanjahe to conduct transaction activities against CU. Where the 
surrounding community can receive payment notifications 3 days before making payments and the latest information that benefits the cooperative members.

Customer relations management is a social part of the use of data mining in accordance with the description or technique that is done. In providing participation, we need a good model of the internet in the form of websites, bloggers, and sites that contain information for the development of a customer relations management system that is automatically centric to the client (Karna, Supriana, \& Maulidevi, 2014).

\section{METHODOLOGY}

In the English dictionary, the word cooperative is cooperative or can also be called cooperative. Where from the word cooperative is concluded a trait that works with each other, hand in hand, or can also be said to help each other in doing business. In other words, this Cooperative aims to improve the living standards of its members and surrounding communities, help the lives of members of the cooperative, especially in the economic field, assist the government in creating balanced and prosperous members or communities, and play a role as building a nationally economic system. (Sitepu \& Hasyim, 2018).

CRM using the linear regression model can help in the process of increasing reciprocal relationships between employees with organizational responses within an internal marketing agency. so that the model can improve relations better by a manager and bank owner. (Therasa, Banu, Gayathri, Gopalakrishnan, \& Manikandan, 2017).Customer relation management using the Scorecard can help in the process of measuring customer satisfaction in the FASILKOM UNSRI canteen. that the seller's performance perspective has a huge impact compared to the perspective of the process, customers and infrastructure (Ibrahim et al., 2018).a large amount of data is needed an architecture in the marketing of paperwork. CRM can help in exploiting the latest data by introducing a CRM architecture that is a new Adaptation architecture (Daif, Eljamiy, Azzouazi, \& Marzak, 2015).In establishing relationships with customers in the Cloud environment a CRM salesforce is needed. As for this CRM salesforce is used so that it can oversee how communication between customers and prospects, so as to find information that is identified. to help the CRM requires a team to collaborate in both remote and non-communication. CRM salesforce also collects experience from online networks, tracks important measurements, and conveys via email, telephone, social, and various channels in order to anticipate what customers want. (Manchar \& Chouhan, 2017).

The analytical model on social CRM undertaken by the Malaysian Institute of Higher Education is how to show the problems that need to be resolved and the actions that must be taken immediately in determining customer satisfaction, loyalty and good reputation. with customers more actively so they can maintain what is expected by the Malaysian Higher Education Institute(Hamid et al., 2018)A broad classification of services using CRM can help in the development of a literature related to the topic and can also be used as a reference, evaluation, and problem solving that has to do with Social CRM. And this social CRM also has an impact on the industry in industrial integration and also information in the field of education which results in a form of service that is in line with the wishes of the customer (Barata, Viana, Reinhold, Lobato, \& Alt, 2018). The characters and conditions in the device have great value in getting the desired results. authenticate files from searching for files needed to have a good customer relationship management application. So customers can easily do a better search for the needs of customers (Ibrahim, Ermatita, Saparudin, \& Adetya, 2017)

Customer Relationship Management is a way of crossing relationships between members and companies in order to strengthen unity in the expected needs so that they become members. Customer 
Relationship Management (CRM) is a marketing strategy that builds a close relationship between a company and its members. The company can spoil the member and bind him in a friendship if he already knows the needs and expectations of the member (Siswanto \& Katili, 2017).CRM system that is made to do buying and selling activities that have been done every day in the business conducted. by using a RAD method can fulfill what the customer wants with a method that is done more quickly and makes it easier for business people in running their business (Fauzi \& Harli, 2017).

\section{RESUlt AND DISCUSSION}

\section{A. Initial Display}

In Fig 1 it can be seen that the main view when opening the system. wherein this view is the view of the user who can only see notifications about the activities performed by CU. Glad that the main display can do our service to members. Where our services are conducted in the form of deposits, loans, special services, and service offices.

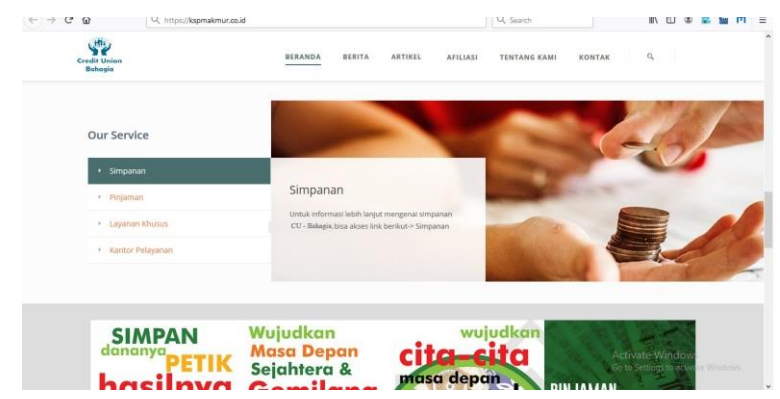

B. The Administrator Dashboard

Fig 1. Initial Dislay

Fig 2 shows that the administrator must primarily enter the username and password to perform activities that can be performed by the administrator. Because in this system, the administrator has full access rights. The administrator can also change the password to a new password.

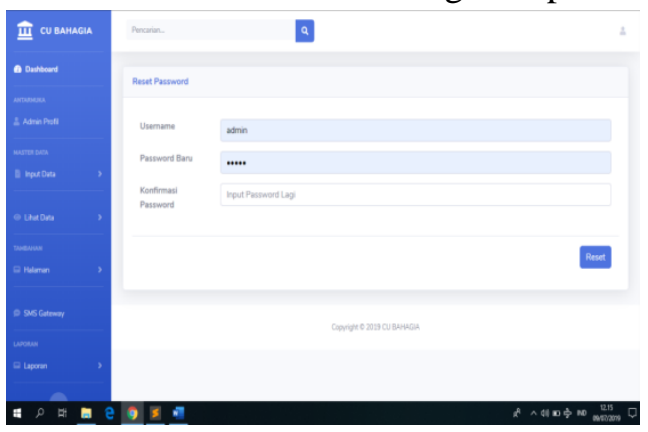

Fig 2. Admin Display

C. Customer Data Entry On The Admin Page

Fig 3 is a screen for entering data for new customers who wish to register as members. When registering, you must have a KTP because the KTP is the primary key in the created system. 


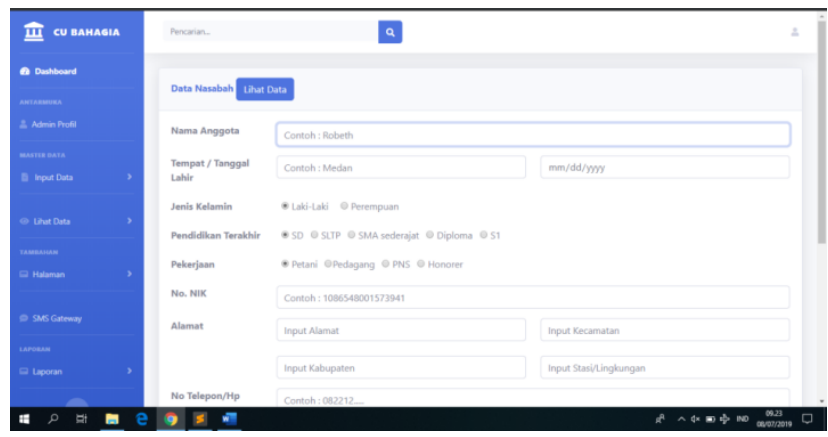

Fig 3. Customer Data Input To Admin

\section{Entered Customer Data}

Fig 4 shows the entered customer data, where the data is book data or biodata summarized in the system.

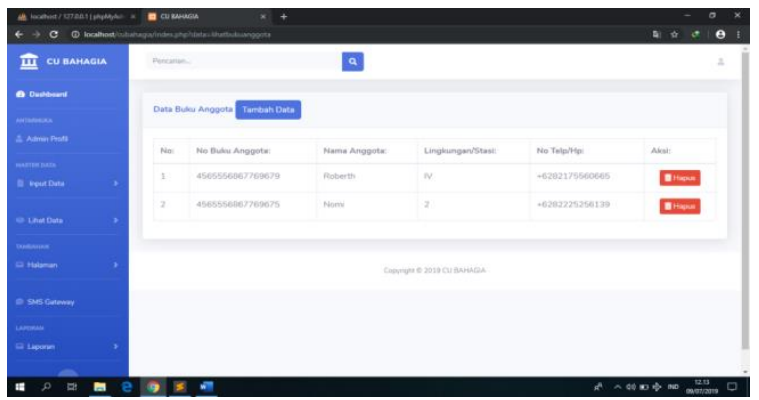

Fig 4 . Entering customer data

\section{E. $\quad$ Sending Message To The Administrator}

Fig 5 illustrates the location of sentences or entries that are sent to the customer to let the customer know which notifications are being sent to the customer. Notifications may take the form of a discussion on bills, CU scholarships, and other news articles that may support activities in the CU work program.

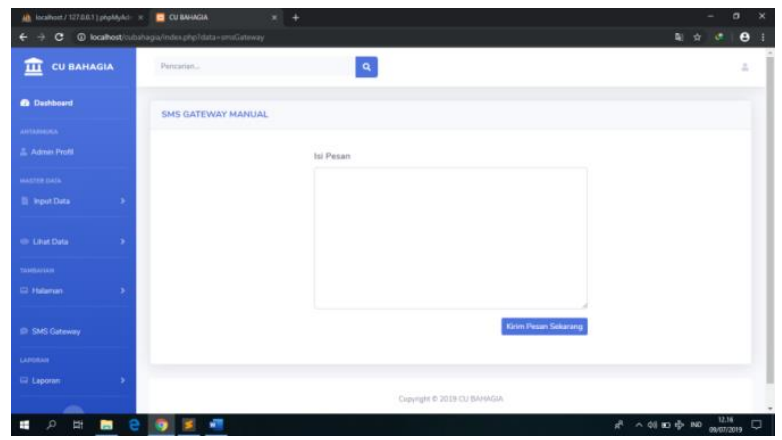

Fig 5 . The location where the message should be filled out to the customer 


\section{F. $\quad$ Received From Customer Via The Handset}

After completing what is sent to the customer, the mobile SMS is entered by the CU. Fig 6 shows a notification to members informing the notification that the bill payment is due on which date and the entire bill is being paid to the CU. Bahagia.

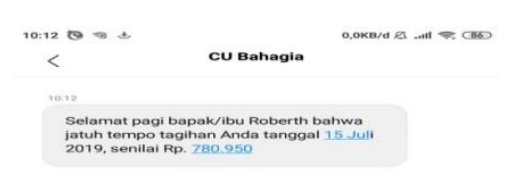

Fig 6. SMS received from the customer

G. Percentage of Systems Built

The percentage can be seen in the Fig below based on bar charts and pie Charts the CRM System.
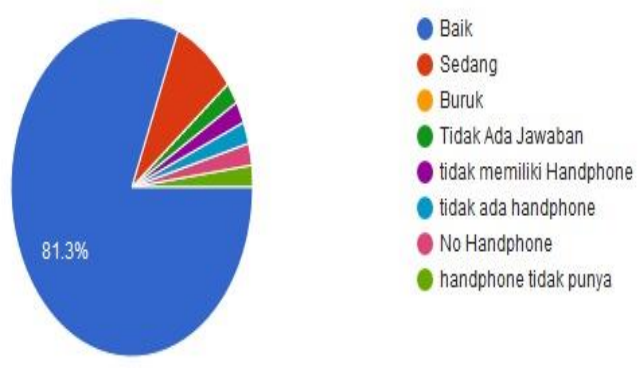

Fig 7 . opinion about the CRM system that was built

Based on Fig 7 can be seen how customer satisfaction with the CRM system (Customer Relationship Management) that has been built was built. The opinion received from cooperative customer members about the CRM system (Customer Relationship Management) made was that $81.3 \%$ stated that the system that had been built was very well used by members of cooperative customers in the Kabajahe area because it made it easier to record in the bill payment process or , $8.3 \%$ stated that the system was not good because of the unattractive display design, $0 \%$ stated that the system had no problems or the system or. $2 \%$ said there was no problem with the system, and $8.4 \%$ stated that they did not have a cellphone so they could not find out how the shapes or images of the SMS received by customers to get the results of the CRM (Customer Relationship Management) system that was built.

\section{Conclusion}

From the above short description, several conclusions can be drawn

Use Of Customer Relationship Management Application For Credit Union Samuel Manurung ${ }^{1}$, Mufria.J.Purba ${ }^{2}$ 
a. This Customer Relation Management application can simplify the process of transactions between $\mathrm{CU}$ and customers.

b. Customers in most regions use mobile phones that are not Android, so they can easily receive messages or events that occur through notifications through the customer's mobile phone.

\section{ACKNOWLEDGMENT}

I as a researcher would like to thank all those involved in this research so that this research went well and the researchers also thanked CU. Happiness has helped researchers as a place for this research..

\section{REFERENCES}

Barata, G. M., Viana, J. A., Reinhold, O., Lobato, F., \& Alt, R. (2018). Social CRM in Digital Marketing Agencies: An Extensive Classification of Services. 2018 IEEE/WIC/ACM International Conference on Web Intelligence (WI), 750-753. https://doi.org/10.1109/WI.2018.00009

Daif, A., Eljamiy, F., Azzouazi, M., \& Marzak, A. (2015). Review current CRM architectures and introducing new adapted architecture to Big Data. 2015 International Conference on Computing, Communication and Security (ICCCS), 1-7. https://doi.org/10.1109/CCCS.2015.7374196

Fauzi, A., \& Harli, E. (2017). Peningkatan Kualitas Pelayanan Melalui CRM dengan Metode RAD. Jurnal RESTI (Rekayasa Sistem dan Teknologi Informasi), 1(1), 76-81. https://doi.org/10.29207/resti.v1i1.16

Hamid, A., Tariqi Raja Lope Ahmad, R. M., Majudi, S., Wan Hassan, W. A., Basri Wan Ismail, W. H., Setik, R., \& Hashim, M. (2018). Social CRM Analytics Model on Malaysian Institutes of Higher Learning (IHLs). 2018 3rd Technology Innovation Management and Engineering Science International Conference (TIMES-ICON), 1-5. https://doi.org/10.1109/TIMESiCON.2018.8621834

Ibrahim, A., Ermatita, Saparudin, \& Adetya, Z. (2017). Analysis of weakness of data validation from social CRM. 2017 International Conference on Data and Software Engineering (ICoDSE), 15. https://doi.org/10.1109/ICODSE.2017.8285849

Ibrahim, A., Pratiwi, A., Meytri, D. I., Madri, Kurniawan, M. A., \& Yuniarti, N. (2018). Measuring Customer Satisfaction Using CRM Scorecard in Canteen FASILKOM UNSRI. 2018 International Conference on Electrical Engineering and Computer Science (ICECOS), 403408. https://doi.org/10.1109/ICECOS.2018.8605253

Karna, N., Supriana, I., \& Maulidevi, U. (2014). Social CRM using web mining. 2014 International Conference on Information Technology Systems and Innovation (ICITSI), 264-268. https://doi.org/10.1109/ICITSI.2014.7048275

Manchar, A., \& Chouhan, A. (2017). Salesforce CRM: A new way of managing customer relationship in cloud environment. 2017 Second International Conference on Electrical, Computer and Communication Technologies (ICECCT), 1-4. https://doi.org/10.1109/ICECCT.2017.8117887

Siswanto, E., \& Katili, A. W. (2017). Implementation of decision support system for campus promotion management using fuzzy multiple analytic decision making (FMADM) method (Case study: Universitas multimedia nusantara). 2017 4th International Conference on New Media Studies (CONMEDIA), 75-80. https://doi.org/10.1109/CONMEDIA.2017.8266034

Sitepu, C. F., \& Hasyim, H. (2018). PERKEMBANGAN EKONOMI KOPERASI di INDONESIA. NIAGAWAN, 7(2). https://doi.org/10.24114/niaga.v7i2.10751

Therasa, C., Banu, C. V., Gayathri, R., Gopalakrishnan, S., \& Manikandan, S. (2017). Linear regression model fit for internal marketing and customer relationship management. 2017 
International Conference on Intelligent Sustainable Systems (ICISS), 927-932. https://doi.org/10.1109/ISS1.2017.8389314 